\title{
The need for quality trade union organisation
}

\begin{abstract}
Over the last thirty years, trade unions everywhere have been going through a period of crises and questioning, i.e. the abandonment of former concepts and ways of doing things. Developments in the global economy have resulted in trade unions being faced with numerous challenges. Recessions in a large number of countries have significantly inhibited the position of trade union members. In Serbia, there has been a noticeable increase in the number of trade union organisations, alongside a decrease in the total number of trade union members. The protection of the rights of employees and improvements in their standard of living are out of the question not only as a result of the bad economic situation but also given the absence of state institutional support. The major goal of this article is to analyse these drawbacks and thus make an effort to improve the position of trade unions. The authors conclude that strong institutional backing, including better respect for the rule of law, is essential if the prospects for trade union action are to be improved in Serbia.
\end{abstract}

Keywords: trade union functions, living standards, economic trends, unemployment, employment rate, poverty, membership decline, fragmentation, marginalisation, leadership alienation, rule of law, workers' rights, social dialogue.

\section{Introduction}

A trade union is a legal entity which is, unlike a corporation, managed in accordance with democratic principles (the rule - one member, one vote). It is an organisation of employees established to negotiate with the employer and provide better status and protection of the rights of employees, as well as to improve the standard of living of workers. ${ }^{1}$

Over the last thirty years, trade unions have evolved in many forms - being influenced by the varying economic and political developments in the environments in which they operate. The modes of action and methods of trade unions are not the same, but they do generally include:

- provision of a variety of benefits for members: in developed countries, unions provide membership benefits through the provision of legal aid; counselling related to education; health and safety; representation in litigation against the employer; and so on

- collective bargaining: a very important aspect of trade union activities, in which trade unions negotiate with employers in order to define the relationship between an employee and an employer

1 www.wikipedia.org. 
- industrial action: trade unions can organise strikes or protests in order to have their demands met

- political activity: trade unions may promote legislative solutions that correspond to the interests of union members by lobbying, supporting certain political parties and candidates, holding discussions with influential people, etc.

A trade union organisation uses the following tools and methods of trade union struggle in order to achieve its objectives, functions and goals: ${ }^{2}$

- it strives for partnership with employers, reconciling divergent interests

- it criticises and challenges certain decisions and actions and delivers its suggestions for alternatives

- it pushes for mediation and arbitration with the aim of a peaceful settlement of conflict issues

- it initiates legal proceedings

- it organises protests and rallies and strikes, in accordance with the law and collective agreements.

A trade union member has the right to:

- protection of their price of labour and other rights specified in collective agreements and under the law

- free legal assistance in the exercise of their rights and in labour-based activities, and representation before employers and management authorities, as well as before judicial and other governmental authorities

- the use of trade union assistance funds

- the prevention of discrimination on the grounds of disability

- minimum paid holidays

- other rights determined by the trade union statute.

Trade union organisations achieve their functions and duties arising from their statute and programme, in the following ways in particular:

- discussing the economic and social status of members; and initiating, requiring and proposing solutions concerning different issues to employers

- proposing to an employer the adoption of acts regulating the economic and social status of employees

- protecting the labour and social rights of employees

- insisting on the creation of conditions in the field of occupational safety and environmental protection at work

- participating in the determination of the principles, criteria and standards for the making of collective agreements and the monitoring of their implementation

- deciding to go on strike, and organising and leading strikes of employees

- proposing and selecting members for trade union roles and to participate on trade union bodies, and monitoring and evaluating their work

- participating in discussions during the making of laws and other regulations that are relevant to the economic and social status of members

- initiating and proposing issues to be determined by the organs and organisations of trade unions

2 http://www.sindikat-obrazovanja.rs. 
- providing conditions for the development of culture, arts, recreation, leisure and physical education

- paying membership affiliation fees in accordance with the decisions taken by the trade union organisation.

As long as there is a division of labour in the process of working between owners (managers) and non-owners (executives), there will be a need for employees to organise into unions in the protection of their own interests.

Over the past thirty years, trade unions have gone through a period of crisis and introspection, in which they have left behind earlier concepts and practices. Developments in the global economy have led to trade unions facing multiple challenges, which certainly include the most fundamental technical innovations (information technology, robotics); the extension of the working life of employees; the steady increase in unemployment; shorter working hours; and contracts for the performance of specific tasks. In addition to this, there is also the creation of a number of trade unions (there are many examples stemming from mutual opposition), despite a continuing reduction in the number of union members in relation to the total number of employees.

\section{The need for quality trade union organising in Serbia}

Over the last twenty years, the Serbian economy has been characterised by negative trends. Most notably among these are a higher rate of unemployment, inflation, the expansion of the grey economy, growing insolvency among companies, foreign debt and corruption. In addition to this, the number of the poor has been growing quickly, while the number of employees has been on the decrease.

In 2011, GDP reached $€ 33 \mathrm{bn}$, just 65 per cent of the 1986 level, which is the most relevant negative indicator. ${ }^{3}$

The number of unemployed people is about 760000 while close to one million people still live below the absolute poverty line. The global economic crisis has led to a reduction in exports, investment and industrial production; this is reflected in a decline in the standard of living and in purchasing power.

GDP per capita in 2011 amounted to $€ 4$ 543. The average net salary in May 2012 amounted to 40442 dinars which, compared to April, was nominally lower in real terms by $4.2 \%$ (and lower than the nominal figure by $5.5 \%$ ). In comparison, the average wage in 2011 was $€ 372.50$. The minimum wage from April to December this year is 20010 dinars, and it is estimated that this amount will be retained for next year.

By May 2012, the average pension paid amounted to 24636 dinars (for employees); 23540 dinars (for the self-employed); and 9503 dinars (for farmers). Particularly disturbing information is that the Pension Fund recorded, in May 2012, a total of 1688576 pensioners, about 100000 more than in 2007. At the same time, the number of employees in April 2012 dropped to 1.734 million and, in comparison to 2007, there were 257000 fewer of them, a drop of 12.91 per cent.

3 http://www.sindikat.rs/aktuelno.html\# Savez samost. sindikata blizu milion stanovnika gladno 24 September 2012. 
According to the Labour Force Survey, the unemployment rate in April was 25.5 per cent, while the employment rate was, on average, 34.3 per cent and even lower for women - just 27.7 per cent.

In-depth economic analysis would include other significant developments in the field of the economy, noting the fall in industrial production in May 2012 of 3.1 per cent compared to the same month last year, as well as the unfavourable balance of exports and imports.

The average consumer basket in May this year has risen to 57920 dinars and its discharge thus required 1.43 average wages.

Making ends meet is not easy for employees, let alone the unemployed and the poor, whose rate, from 6.1 per cent in 2008, increased to 11 per cent in 2011 according to trade union analysts.

Calculations on particular consumer prices also show a decline: in June 2012 they had increased by 5.5 per cent compared to June 2011 and, in comparison to December 2011 , by 5.2 per cent.

The relationship between the registered number of employees and the number of pensioners in May was a critical 1.02:1: an employment base of 1.734 million compared to 1.689 million registered pensioners. The average pension was just 62.1 per cent of the average net wage, with the average pension being 23200 dinars compared to an average wage of 40442 dinars, according to trade union analysis. This should be the basis for taking a stance and for further guidance in the work of the trade unions, as well as acting as a warning to economic policy-makers, although this has, in previous years, not produced satisfactory results. ${ }^{4}$

These negative trends in the economy of Serbia indicate the necessity for quantitative and qualitative, and more uniform, change, as well as for union activities which are oriented more to making overall changes in the economic environment for the better.

\section{Problems of trade union organising in Serbia}

A successful strategy in establishing social dialogue and social consensus around the interests of employees is of crucial importance for trade unions in post-communist societies in transition. These countries, in the last decade of the $20^{\text {th }}$ century, saw the greatest decline in trade union membership - about 50 per cent - and it is increasingly evident that new members cannot be found among the ruined communist industrial giants but in small- and medium-sized enterprises and the informal economy, as well as among the unemployed.

The main reasons for the decrease in membership numbers and in the rates of trade union membership among employees, in addition to privatisation and the restructuring of enterprises, are the reduction in the share of production activities and the lack of organisational capacity to form trade unions in new sectors, as well as to widespread 
scepticism that union employees can themselves successfully protect the rights and interests of their members. ${ }^{5}$

According to various sources, the number of trade unions in Serbia ranges from 20000 to 26000 . The total number of employees is about $1.75 \mathrm{~m}$, and it is difficult to find accurate data on the number of workers affiliated to trade unions (it ranges from $25 \%$ to $33 \%$, or 425000 to 560000 ). Professor Darko Marinković ${ }^{6}$ claims:

In this country, according to data from the latest barometer of trade unions, that the rate is 25 per cent. Four or five years ago, it was 70-80\%, and I would be delighted if it would remain at 25 per cent given the downwards trend.

Regardless of the necessity of 'pluralist union organising', it is clear that this number is too high and that the differences in aspirations, ideas, modes of action and interests, especially among the leaders of unions, have caused a significant reduction in the success rates of trade unions at the national level. The sheer number and the depth of fragmentation is a consequence of individuals striving for leadership and the achievement of the personal gains and privileges of trade union leaders.

The law regulates that union members can be members of the executive board (a paid function) and, as a rule, they are union leaders or the people who are closest to them. In this way, benevolent leaderships are being bought (by employers), with the result that the leaders 'lose connection with the membership', not in a position completely to feel the weight of members' current difficulties.

The issue of relationships between trade unions and political parties is always a topical issue. There exists a connection embodied primarily in that all union members also vote in elections and are supporters of the various parties. Also, the parties in power are the ones who create the economic environment, make laws and directly affect the position of union members. Shortly before the 2012 elections, action was initiated by political parties in order to gain favour with certain unions (with the primary aim of increasing the 'voting machine'). However, fortunately, the end result was that unions stood by and that the membership, without instructions from their union leaders, were able to make decisions without pointing their trust at their leaders' political pets (with the exception of the Association of Free and Independent Trade Unions, which openly sided with the Preokret coalition).

We live in a country in which the rule of law does not work, the courts are often not independent in making judgments and where 'tycoons', as well as employers across the state authorities, have the ability to act in conflict with respect to legislation and union expectations. The consequence is labour court claims, brought over several years, where employers have been paying the minimum price of labour, or where salaries are unpaid over several months, as a means of avoiding the payment of taxes and contributions for their employees, in addition to a host of other activities that are directly aimed against workers and union members. The moment we provide a fully indepen-

5 Stojiljković, Z Sindikati u lavirintu promena http://www.fpn.bg.ac.rs/wp-content/uploads/ 2010/03/ Sindikati u lavirintu promena2.pdf.

6 Marinković, D Šta to beše solidarnost Ilustrovana politika, http://www.ilustrovana.com/ tekst.php?broj $277=\&$ tekst $=02$. 
dent judiciary, with a set of appropriate legislative tools, we will have secured the substantial assistance of the state to all unions.

The high unemployment rate means that it is common for employers to threaten the cancellation of contracts, placement in poor jobs or otherwise the blackmail of leaders and union members, thus causing fear and hindering them in their struggle for their rights.

\section{Conclusion}

Over the last twenty years, the Serbian economy has been characterised by negative trends as regards unemployment, inflation, the grey economy, company insolvency, foreign debt and corruption. On top of these, the number of the poor is growing while the number of employees is on the decline.

These negative trends, in addition to the need to shore up the economy in the face of the global economic crisis and the painful transition period, have made today one of the most difficult periods in the struggle for workers' rights. Trade union activities have not achieved the desired results, but it is certainly evident that, where trade unions exist, there are fewer violations of workers' rights.

It is necessary to provide continuing activities to improve the relationship between unions and employers, as the key to economic success is respect for basic workers' rights - a prerequisite for their maximum engagement in their jobs. Tripartite co-operation is a good way to overcome the difficulties experienced by developing economies.

It is difficult to argue with Ljubisav Orbović, the President of Savez Samostalnih Sindikata Srbije, when he says:

The difficult economic crisis, loss of jobs, low wages and the standard of equity and employers whose goal is to increase profits at the expense of workers, global financial institutions and corporations, and pressures to reduce the rights of workers on a daily basis in the absence of mechanisms that can protect workers and citizens, is the spectre that, in the future, we must vigorously oppose. And to achieve that we need solidarity and joint action and mutual support, which are the main objectives of the Regional Council of Trade Unions of the former Yugoslav republics. ${ }^{7}$

For all these problems, there is real concern that the reduction in the number of workers in unions, union fragmentation and the alienation of union principles in the circumstances of a poor functioning of the rule of law, may significantly reduce the strength of trade union action up to the point of unions' complete marginalisation.

Most developed countries in western Europe, which have stable and strong trade unions, have strong institutional backing, guaranteed by the state, which is both a necessity and an obligation on public authorities if the conditions for, and then the results of, trade union action are to be improved.

7 www.sindikat.rs/aktuelno.html. 


\section{References}

Marinković, D Šta to beše solidarnost Ilustrovana politika http://www.ilustrovana.com/tekst.php?broj $277=\&$ tekst $=02$.

Autonomous Trade Unions of Serbia (2012) Near one million people are hungry, 24 September 2012 http://www.sindikat.rs/aktuelno.html\#.

Stojiljković, Z Sindikati u lavirintu promena http://www.fpn.bg.ac.rs/wp-content/uploads/2010/03/Sindikati u lavirintu promena2.pdf.

http://www.sindikat-obrazovanja.rs.

www.sindikat.rs/aktuelno.html.

www.wikipedia.org. 